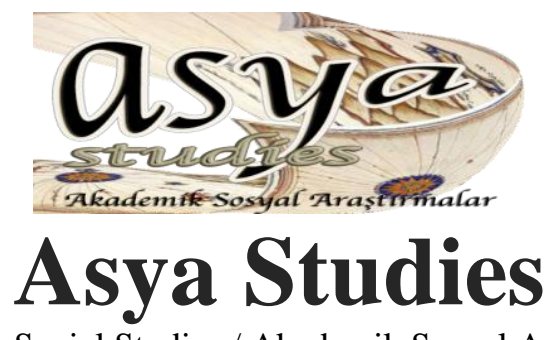

Academic Social Studies / Akademik Sosyal Araştırmalar

Year: 5 - Number: 18, p. 109-119, Winter 2021

\title{
Üniversite Öğrencilerinin Koronavirüs Salgını Sürecindeki Dijital Oyun Bağımlılıklarının İncelenmesi*
}

\author{
Investigation of University Students' Digital Game Addiction During The Coronavirus \\ Outbreak Process
}

\section{DOI: https://doi.org/10.31455/asya.990464}

Araştırma Makalesi / Research Article

Makale Geliş Tarihi / Article Arrival Date 02.09.2021

Makale Kabul Tarihi / Article Accepted Date 03.11.2021

Makale Yayın Tarihi / Article Publication Date 31.12.2021

\section{Asya Studies}

Abdulhakim Öztekin Yüksek Lisans Öğrencisi / Muş Alparslan Üniversitesi, Sosyal Bilimler Enstitüsü, a.hakim.oztekin@gmail.com ORCID ID

https://orcid.org/0000-0002-9359-747X

Nihat Kavan

Bilim Uzmanı,

nihatkavan@gmail.com ORCID ID

https://orcid.org/0000-0003-4872-1002

Metin Dündar

Öğretmen / Millî Eğitim Bakanlığı, metin.dundar@std.hku.edu.tr ORCID ID

https://orcid.org/0000-0002-1424-129X

İdris Meriç

Lisans Mezunu / Rehberlik ve Psikolojik

Danışmanlık Bölümü,

meric.9490@gmail.com ORCID ID

https://orcid.org/0000-0001-9032-6079

* "COPE-Dergi Editörleri İçin Davranıș Kuralları ve En İyi Uygulama İlkeleri” beyanları: Bu çalışma için herhangi bir çıkar çatışması bildirilmemiştir. $\mathrm{Bu}$ çalışma Mardin Artuklu Üniversitesi Bilimsel Araștırma ve Yayın Etiği Kurulu'nun 31.03.2021 tarih ve 2021/3-15 sayilı karar onayı çerçevesinde gerçekleştirilmiştir.
Öz

Teknolojideki gelişmeler beraberinde insanların oyun algısını değiştirmekte ve insanlar üzerinde çeşitli bağımlılıklar yaratmaktadır. Dijital oyunlarda bağımlılık düzeyinin artması ile birlikte dijital oyun bağımlılık düzeylerinin incelenmesi önem arz etmektedir. $\mathrm{Bu}$ araştırmada, koronavirüs küresel salgını sürecinde üniversite öğrencilerinin dijital oyun bağımlılık düzeylerinin incelenmesi amaçlanmıştır. Araştırma verileri nicel araştırma yöntemlerinden tarama deseni kullanılarak elde edilmiştir. Araştırmanın evrenini Mardin Artuklu Üniversitesinde öğrenim görmekte olan ön lisans ve lisans öğrencileri oluşturmaktadır. Araştırmanın örneklemini ise basit seçkisiz örnekleme yöntemiyle seçilen 73'ü kadın, 54'ü erkek olmak üzere 127 üniversite öğrencisi oluşturmaktadır. Araştırmada Türkçeye uyarlaması yapılmış olan dijital oyun bağımlılığ1 ölçeği kullanılmış ve anket formu katılımcılara çevrim içi ortamda sunulmuştur. Araştırma verilerinin analizinde SPSS 25.00 paket programı kullanılmış olup kullanılan istatistiksel işlemlerde t-testi, tek yönlü varyans analizi, standart sapma, ortalama gibi analizler kullanılmıştır. Ulaşılan verilerle yapılan analizler sonucunda koronavirüs küresel salgını sürecinde üniversite öğrenimine devam eden öğrencilerin dijital oyun bağımlılıkları düzeylerinde oynanan dijital oyun türü, kullanılan cihaz türü, bağımlılık yapıcı madde kullanımı, akademik başarı düzeyi değişkenlerine ilişkin istatistiksel olarak anlamlı bir farklılık bulunmuştur. Buna karşın incelenen diğer değişkenler olan fiziksel etkinliklere katılma durumu, bulunulan sınıf düzeyi, bulunulan yaş aralıkları, kullanılan internet türü değişkenine ilişkin istatistiksel olarak anlamlı bir farklılığa ulaşılamamıştır.

Anahtar Kelimeler: Bağımlılık, Teknoloji, Dijital Oyun, Koronavirüs, Üniversite Öğrencileri

\section{Abstract}

In this research, it is aimed to examine the digital game addiction levels of university students during the coronavirus global epidemic. The research data were obtained by using the survey design, one of the quantitative research methods. The universe of the research consists of associate and undergraduate students studying at Mardin Artuklu University. The sample of the study consists of 127 university students, 73 female and 54 male, selected by simple random sampling method. The digital game addiction scale, which was adapted into Turkish, was used in the study and the questionnaire form was presented to the participants online. SPSS 25.00 package program was used in the analysis of the research data, and analyzes such as $t$-test, oneway analysis of variance, standard deviation, and mean were used in statistical operations. As a result of the analyzes made with the data obtained, a statistically significant difference was found in the digital game addiction levels of the students who continued their university education during the coronavirus global epidemic, regarding the variables of type of digital game played, type of device used, addictive substance use, and academic achievement level. On the other hand, there was no statistically significant difference in the variables of participation in physical activities, class level, age ranges, and type of internet used, which are the other variables examined.

Keywords: Addiction, Technology, Digital Game, Coronavirus, University Students

\section{Citation Information/Kaynakça Bilgisi}

Öztekin, A.; Kavan, N.; Dündar, M. ve Meriç, İ. (2021). Üniversite Öğrencilerinin Koronavirüs Salgını Sürecindeki Dijital Oyun Bağımlılıklarının İncelenmesi. Asya Studies-Academic Social Studies / Akademik Sosyal Araşttrmalar, 5(18), 109-119. 


\section{GíRiș}

2020 yılı koronavirüs sebebiyle bütün dünyada yeni bir dönemin başlangıcı olmuştur. Koronavirüs ilk olarak 31 Aralık 2019 yılında Çin'de bulunan Hubei eyaletinin başkenti Wuhan'da Çinli yetkililer tarafından henüz bilinmeyen bir virüs olarak dünya sağlık örgütüne bildirilmiştir (Zhu, Zhang ve Wang, 2020). Dünya Sağlık Örgütü bir hastalığın pandemi olarak ilan edilmesi için kriterler belirlemiştir. Bu kriterler hastalığın insanlar arasında yayılmasına neden olan yeni bir virüsün olması, bu virüsün insanları kolay bir şekilde, hızlı ve sürekli olarak etkilemesi gibi özellikleri taşımasından dolayı pandemi olarak ilan eder (Türkiye Bilimler Akademisi [TÜBA], 2020). Koronavirüsün pandemi özellikleri taşıması, hızla yayılması ve tüm dünyayı etkisi altına alması sebebiyle Dünya Sağlık Örgütü tarafından pandemi yani küresel salgın olarak ilan edilmiştir (Ghebreyesus, 2020; Cucinotta ve Vanelli, 2020).

Ülkemizde ilk koronavirüs vakası 2020 yılında mart ayının 11'inde tespit edilmiş ve ilk koronavirüsten kaynaklanan ölüm 17 Mart’ta yetkililer tarafından bildirilmiştir (T.C. Sağlık Bakanlığı, 2020). Koronavirüs küresel salgını sonucunda vaka ve ölüm sayılarındaki artıştan dolayı her devlet koronavirüsle mücadele konusunda birtakım tedbirler almış ve koronavirüsle mücadele etmeye çalışmışlardır (Fernandes, 2020; Ho, Chee ve Ho, 2020; Zheng, Goh ve Wen, 2020). Koronavirüs küresel salgını ile birlikte dünyada birçok ülkede kültürel, ekonomik ve sosyal hayatla ilgili birçok kısıtlama meydana gelmiştir. Birçok ülke eğitime ara vermiş sosyal, ekonomik ve kültürel etkinliklerde özellikle insanların toplu olarak yaptıkları etkinliklerde kısıtlamalara gidilmiştir. Eğitimde uzaktan eğitime, iş yaşamında evden çalışma sistemine geçilmiş ve yurt içi, yurt dışı seyahat kısıtlamaları gibi kısıtlamalar getirilmiştir.

Türkiye'de koronavirüs küresel salgını ile birlikte sosyal, ekonomik, kültürel ve dini hayatta birçok kısıtlama getirilmiştir. İnsan yaşamına kısıtlama getirilmesinin sebebi kalabalık ortamlarda insanların yakın mesafede bulunmasından dolayı bulaşma hızının yüksek olması ve ölümcül etkilerde bulunmasından dolayıdır (Hoque vd., 2020). Türkiye de getirilen kısıtlamalar ile birçok radikal karar alınmıştır. Alınan bu kararlar sadece sağlık açısından değildir. Eğitim, hukuki, dini ve askeri tedbirler başta olmak üzere sosyal siyasi ve ekonomik olarak radikal kararlar alınmıştır. Alınan kararlardan birisi de üniversite ve orta dereceli eğitim kurumlarının öğretim hizmetlerine uzaktan eğitim şeklinde devam etmesi yönünde olmuştur (Demir ve Özdaş, 2020). Sonrasında ise bunu takiben birçok kısıtlama kararı daha gelmiştir.

Koronavirüs küresel salgını sonucunda insanların sosyal hayattan uzaklaşması, karantina yaşamına girmesi insanları teknolojiye daha da yaklaştırmış hatta insanlarda bağımlılıklar oluşturmuştur. Bilgisayarlar, akıllı telefonlar, tabletler ve daha birçok teknolojik alet internet ile birlikte pek çok alanda insan yaşamını kolaylaştırmıştır. İnsan yaşamını kolaylaştırmasının yanında eğlence ve oyun aracı olarak giderek yaygınlaşan bir alan hâline gelmiştir. Her geçen gün teknolojinin bir adım daha ileri gitmesi insanların günümüzde bilgiye nasıl ulaşılacağı, elde edilen bilgilerin yapılandırılması ve yeni bilgilerin üretilmesi gibi temel öğrenme becerileri, aktif öğrenme, problem çözme, öğrenmeyi öğrenme, iş birliği ve iletişim becerilerinin önemini arttırmıştır (Çakmak, Özdaş ve Akın, 2020). İnsanların teknoloji ile iç içe olması geleneksel oyunlardan uzaklaşması oyun etkinliklerinin teknolojiye bağlı oyunlar olan dijital oyunların yer almasına neden olmuştur. Tüm yaşlarda kullanıcısı olan dijital oyunlar gençlerin özellikle yoğun ilgi gösterdiğini göstermekle birlikte giderek oyun oynadıkları süreyi ve ilgiyi arttırmaktadır (Gentile 2009, Rideout vd., 2010). Her insan yaşam boyu eğitim sistemi içerisinde yer almakta ve eğitim sisteminde oluşan durumlardan etkilenmektedir (Evran Acar, 2010). Teknolojide yaşanan gelişmeler hayatın her alanında değişikliklere neden olmuş ve insanların birçok alışkanlığını değiştirmiştir. Teknolojideki bu gelişmeler ve dijital oyun ortamlarının gelişmesi insanlardaki oyun algısını değiştirmiş, yeniden şekillendirmiş ve dijital oyun kavramını ortaya koymuştur (Ülker, Acar ve Bülbül, 2017).

Dijital oyunlar bilgisayar tabanlıdır ve bilgisayar, oyun konsolu gibi elektronik ortamlar üzerinde metin ya da görsellik üzerine inşa edilmiş bir ya da daha fazla kişinin çevrim içi ağ üstünden birlikte kullandıkları boş zaman ve eğlence yazılımıdır (Ankara Kalkınma Ajansı, 2016). Dijital oyunların insanlarda davranışsal bir bağımlılık olarak ifade edilebilmesi için bireyin dijital oyun oynama isteğini kontrol edememesi, sürekli dijital oyun oynama isteği olması, davranışlarında, düşüncelerinde, duygularında ve günlük yaşamında dijital oyun oynamaktan dolayı bozukluk veya bozukluklar oluşturduğu durumdur. Oluşan bu bağımlılıkta birey kullandığı nesne üzerinde kontrolünü kaybetmektedir ve onsuz bir hayata devam edememektedir. Bireyin davranışındaki irade kalkar ve istemediği hâlde bu bağımlı davranışı sürdürmeye devam eder. Bu dijital oyun veya oyunlar bireyin 
hayatının çok önemli bir bölümünü kaplar birey yapmak zorunda olduğu önemli işleri ve ilişkileri dışındaki tüm vaktini, fiziksel enerjisini çok büyük oranda bağımlı olduğu bu maddeye ya da eyleme harcamaktadır (Kodaman ve Dinç, 2016).

Dijital oyun bağımlılı̆g 1 olan bireylerde dopamin üretiminin yetersiz olduğundan dolayı birey bağımlı olduğu davranışa yönelir haz ve ödül sistemlerini dijital oyunlardan sağladığı etkiyle çözmeye çalışır (Tarhan, 2016). Bağımlılık yapıcı maddeler kullanan bireyler genellikle kendilerindeki stres ve endişeyi azaltmak için yaşadıkları depresif ruh hâlini azaltmaya ve zor düşüncelerinden günlük yaşadıkları sorunlardan kaçınmak için bağımlılık yapıcı maddelere başvururlar (Király, Potenza ve Stein, 2020). Koronavirüs salgını gibi küresel bir krizin etkilerinden kurtulmak için ya da etkilerini azaltmak için insanlar bağımlılık yapıcı maddelere başvurabilir ve bu maddelerin kullanımında artış yaşayabilirler. Çünkü koronavirüs hayatın birçok alanında insanların yaşamına kısıtlamalar getirmiş ve de insanların Psikolojik olarak ruh hâllerini önemli ölçüde etkilemiştir.

Sosyal Medya ve Dijital Güvenlik Eğitim, Uygulama ve Araştırma Merkezinin yaptığı araştırma sonucuna göre koronavirüs küresel salgını sürecinde insanların dijital oyun oynanan ortamlarda, cep telefonları, bilgisayarlar ile geçirdikleri sürede büyük ölçüde artış olduğunu belirtmiş ve karantina sürecinden dolayı evde geçen zamanda dijital oyun oynamada en büyük artışın 18-24 yaş aralı̆ğında bulunan bireylerde olduğunu belirtmiştir. Bulunulan yaş aralığ itibari ile 18-24 yaş döneminde bulunan üniversite öğrencilerinin diğer bulunulan yaş aralığındaki öğrencilere göre bağımsız yaşamalarından dolayı telefon, tablet, bilgisayar ve daha birçok oyun aracına ve internete rahat erişebilmeleri nedeni ile dijital oyun oynamada daha fazla zaman geçirdikleri düşünülmektedir (Hazar ve Hazar, 2019). Bu açıdan bakıldığında dijital oyun kullanımın bağımlılık düzeyine ulaşmasında koronavirüs küresel salgını sürecinde koronavirüsün üniversite öğrencilerinin dijital oyun oynama ve oluşan bağımlılık düzeylerine etkisinin ölçülmesinin literatüre katkı sağlayacağı düşünülmektedir.

$\mathrm{Bu}$ araştırmanın amacı koronavirüs küresel salgını sürecinde üniversite öğrencilerinin dijital oyun bağımlılık düzeylerinin incelenmesidir. Araştırma koronavirüs salgını sürecinde teknolojik bağımlılık düzeyi artan toplumda üniversite öğrencilerinin dijital oyunlara yönelimleri ve bağımlılık düzeylerinin incelenmesi açısından önem arz etmektedir. Alt problemler şu şekildedir: Üniversite öğrencilerinin cinsiyet değiş̧kenine göre dijital oyun bağımlılık düzeylerinde anlamlı bir fark var mıdır?

1. Üniversite öğrencilerinin oynadıkları dijital oyun türü değişkenine göre dijital oyun bağımlılık düzeylerinde anlamlı bir fark var midır?

2. Üniversite öğrencilerinin kullandıkları internet türü değişkenine göre dijital oyun bağımlılık düzeylerinde anlamlı bir fark var midır?

3. Üniversite öğrencilerinin bulundukları yaş aralıkları değişkenine göre dijital oyun bağımlılık düzeylerinde anlamlı bir fark var midir?

4. Üniversite öğrencilerinin kullandıkları teknolojik cihaz değişkenine göre dijital oyun bağımlılık düzeylerinde anlamlı bir fark var mıdır?

5. Üniversite öğrencilerinin bulundukları sınıf düzeyi değişkenine göre dijital oyun bağımlılık düzeylerinde anlamlı bir fark var mıdır?

6. Üniversite öğrencilerinin fiziksel etkinliklere katılma durumu değişkenine göre dijital oyun bağımlılık düzeylerinde anlamlı bir fark var mıdır?

7. Üniversite öğrencilerinin bağımlılık yapıcı madde kullanım durumu değişkenine göre dijital oyun bağımlılık düzeylerinde anlamlı bir fark var mıdır?

8. Üniversite öğrencilerinin akademik başarı düzeyleri durumu değişkenine göre dijital oyun bağımlılık düzeylerinde anlamlı bir fark var mıdır?

\section{YÖNTEM}

\section{Araştırmanın Modeli}

Koronavirüs küresel salgını sürecinde üniversite öğrencilerinin dijital oyun bağımlılık düzeylerinin incelendiği bu çalışmada nicel araştırma yöntemlerinden tarama araştırma yöntemi kullanılmıştır. Tarama araştırma modelleri çok sayıda birimden oluşan evren hakkında genel bir yargıya varmak amacıyla evrenin bütününden veya bir grubundan alınacak olan örneklem üzerinde yapılan bir çalışma modelidir. $\mathrm{Bu}$ araştırma modelleri geçmişte veya günümüzde olan bir durumu betimlemeyi amaçlayan bir araştırma modelidir. Tarama araştırma modellerinde araştırmaya konu olmuş birey, olay veya nesne kendi koşulları içinde ve olduğu şekliyle betimlenmeye çalışılır (Karasar, 2012). 


\section{Evren ve Örneklem}

Araştırmanın evrenini Mardin Artuklu Üniversitesinde öğrenim görmekte olan ön lisans ve lisans öğrencileri oluşturmaktadır. Araştırmanın örneklemini ise basit seçkisiz örnekleme yöntemiyle seçilen 73'ü kadın, 54'ü erkek olmak üzere 127 üniversite öğrencisi oluşturmaktadır. Salgın sürecinde olunması ve üniversitelerin eğitim faaliyetlerini uzaktan eğitim şeklinde sürdürmesi sebebiyle araştırma için katılımcılara çevrim içi anket sistemi ile ulaşııııștır. Araştırma, anketi cevaplamayı kabul eden gönüllü katılımcılarla gerçekleştirilmiştir. Katılımcıların demografik özelliklerine ilişkin veriler Tablo 1 'de sunulmuştur.

Tablo 1: Katılımcılara İlişkin Demografik Veriler

\begin{tabular}{llll}
\hline Değişken & Alt Değişken & $\boldsymbol{f}$ & $\boldsymbol{\%}$ \\
\hline \multirow{2}{*}{ Cinsiyet } & Kadın & 73 & 57,48 \\
& Erkek & 54 & 42,51 \\
\hline \multirow{4}{*}{ Sınıf Düzeyi } & 1. Sınıf & 46 & 36,22 \\
& 2. Sınıf & 26 & 20,47 \\
& 3. Sınıf & 27 & 21,25 \\
& 4. Sınıf & 28 & 22,04 \\
\hline \multirow{3}{*}{ Yaş Aralığı } & 20 Yaş ve Altı & 43 & 33,85 \\
& 21-24 Yaş Arası & 60 & 47,24 \\
& 25 Yaş ve Üstü & 24 & 18,89 \\
\hline
\end{tabular}

Tablo 1'de yer alan veriler incelendiğinde bu araştırmaya 73 kadın ve 54 erkek olmak üzere 127 kişinin katılımda bulunduğu görülmektedir. Katılımcıların sınıf düzeyleri incelendiğinde 1 . sınıf düzeyinde $46(\% 36,22), 2$. sinıf düzeyinde $26(20,47), 3$. sinıf düzeyinde $27(\% 21,25)$ ve 4 . sinıf düzeyinde 28 (22,04); katılımcıların yaş aralığı incelendiğinde 20 yaş ve altında $43(\% 33,85), 21-24$ yaş arasında $60(\% 47,24), 25$ yaş ve üstünde ise $24(\% 18,89)$ öğrencinin araştırmaya katıldığı görülmektedir.

\section{Veri Toplama Araçları}

Tarama araştırma yöntemlerinde kullanılan yöntemlerden birisi de ölçeklerdir ve bu çalışmada geçerliği ve güvenirliği yüksek bir ölçek olan dijital oyun bağımlılığı ölçeği kullanılmıştır. Dijital oyun bağımlılı̆̆ ölçeği Lemmens vd. (2012) tarafindan geliştirilmiş olup Hazar ve Hazar (2019) tarafından Türkçe geçerlik ve güvenirlik çalışması yapılmıştır.

Dijital oyun bağımlılı̆̆ ölçeği 5 'li likert tipinden oluşmaktadır. Dijital oyun bağımlılı̆̆ı ölçeğinde kullanılan puanlama sistemi kesinlikle katılmıyorum 1 puan, katılmıyorum 2 puan, kararsızım 3 puan, katılıyorum 4 puan ve tamamen katılıyorum 5 puan olarak belirlenmiştir. Dijital oyun bağımlılığ ölçeğinden alınan toplam puanlarda dijital oyun bağımlılığın düzeyi için bazı puan aralıkları belirlenmiştir. Bu bağımlılık düzeyleri şu şekilde ifade edilmektedir. Normal grup 1-21 puan, az riskli grup 22-42 puan, riskli grup 43-63 puan, bağımlı grup 64-84 puan, yüksek düzeyde bağımlı grup ise 85105 arası puan olarak belirlenmiştir. Dijital oyun bağımlılığı ölçeğinden alınan toplam puanlar bireylerin hangi bağımlılık düzeyinde olduğunu göstermektedir.

\section{Verilerin Toplanması}

Tarama yöntemi ile verilerin toplandığı bu çalışmada salgın sürecinde olunması ve üniversitelerin eğitim faaliyetlerini uzaktan eğitim şeklinde sürdürmesi sebebiyle araştırma için katılımcılara çevrim içi ortamdan ulaşılmıştır. Araştırma verileri toplanmadan önce Mardin Artuklu Üniversitesi Bilimsel Araştırma ve Yayın Etiği Kurulundan etik kurul onayı ve Mardin Artuklu Üniversitesinden araştırma izni alınmıştır.

Araştırmada kullanılan dijital oyun bağımlılı̆̆ı ölçeği için ise ölçme aracını geliştiren araştırmacılardan e-posta aracılığıyla izin alınmıştır. Gerekli izinler alındıktan sonra dijital oyun bağımlılı̆̆ ölçeği sanal anket aracılığı ile hazırlanarak katılımcılara sunulmuştur. Araştırmaya katılımda gönüllü esası gözetilerek katılımcılardan kişisel veri talep edilmemiştir. 


\section{Verilerin Analizi}

Oluşturulan sanal anket formu aracılığıyla toplanan verilerin analizinde SPSS 25.00 programı kullanılmıştır. Değişkenlerin belirlenmesinde ise ortama, yüzde, frekans, standart sapma ve anlamlılık değerleri kullanılmıștır. Değișkenler t testi ve ANOVA testleri ile analiz edilmiștir.

Dijital oyun bağımlılığı ölçeği için cronbach Alpha güvenirlik katsayısı kullanılarak güvenirlik analizi yapılmıştır. Ölçeğe ilişkin güvenirlik analizi sonucu Tablo 2'de sunulmuştur.

Tablo 2: Dijital Oyun Bağımlılı̆̆g Ölçeğine Ait Cronbach Alpha Güvenirlik Analizi

Cronbach Alpha Değeri $\quad$ Madde Sayısı

Tablo 2'deki verilere bakıldığında dijital oyun bağımlılığı ölçeği 21 maddeden oluşmaktadır. Yapılan analiz sonucunda cronbach alpha iç tutarlık katsayısı 0,96 olarak bulunmuştur. Güvenirlik analizi sonucunda bulunan .964 değeri, ölçeğin .80 ile 1 aralığında bir değere sahip olduğunu ve dijital oyun bağımlılığı ölçeğinin çok yüksek bir güvenirliğe sahip olduğunu göstermektedir.

\section{BULGULAR}

Birinci Alt Probleme İlişkin Bulgular

Araştırmanın "Üniversite öğrencilerinin oynadıkları dijital oyun türü değişkenine göre dijital oyun bağımlılık düzeylerinde anlamlı bir fark var mıdır?” alt problemine ilişkin bulgularına Tablo 3'te yer verilmiştir.

Tablo 3: Dijital Oyun Türü Değişkenine İlişkin Veriler

\begin{tabular}{lcccc}
\hline Dijital Oyun Türü & $\mathbf{N}$ & $\overline{\mathbf{X}}$ & SD & $\mathbf{p}$ \\
\hline Savaş ve Strateji & 36 & 53,75 & 17,50 & \\
Bulmaca ve Zekâ & 66 & 37,10 & 14,01 & .000 \\
Spor & 14 & 59,57 & 20,09 & \\
Macera & 11 & 50,45 & 22,50 & \\
\hline Toplam & 127 & 45,45 & 18,67 & \\
\hline
\end{tabular}

Yapılan analiz sonucunda Tablo 3'teki verilere bakıldı̆̆ından katılımcıların 36'sının savaş ve strateji dijital oyununu oynadığı, 66'sının bulmaca ve zekâ dijital oyununu oynadığı, 14'ünün spor dijital oyununu oynadığı ve 11'inin de macera türü dijital oyununu oynadığı görülmektedir. Yapılan ANOVA analizi sonucunda bulunan $\mathrm{p}$ değeri .000 çıkmıştır. Bulunan bu değer ve $\mathrm{p}<.05$ alpha değerinden küçük olduğundan dolayı koronavirüs küresel salgını sürecinde üniversite öğrencilerinin dijital oyun bağımlılıkları düzeyinde istatistiksel olarak anlamlı bir fark bulunmaktadır. Katılımcıların dijital oyun bağımlılı̆̆ ölçeğinden alınan ortalama puanlarına bakıldığında en yüksek puanın 59,57 puan ile spor dijital oyun türünde, en düşük puanın ise 37,10 puan ile bulmaca ve zekâ dijital oyunu oynayan katılımcılara ait oluğu görülmektedir. Dijital oyun bağımlılığı ölçeğinden alınan puanlarda spor, macera, savaş ve strateji oyunlarının 43-63 arası puana sahip olması bu oyun türünün oynayanların riskli grupta olduklarını göstermektedir.

\section{İkinci Alt Probleme İlişkin Bulgular}

Araştırmanın "Üniversite öğrencilerinin kullandıkları internet türü değişkenine göre dijital oyun bağımlılık düzeylerinde anlamlı bir fark var mıdır?” alt problemine ilişkin bulgularına Tablo 4'te yer verilmiştir.

Tablo 4: Kullanılan İnternet Türü Değişkenine İlişkin Veriler

\begin{tabular}{lccccc}
\hline Internet Türü & $\mathbf{N}$ & $\mathbf{\%}$ & $\overline{\mathbf{X}}$ & $\mathbf{S D}$ & $\mathbf{p}$ \\
\hline Mobil İnternet & 47 & 37 & 47,04 & 21,69 & .465 \\
Sabit İnternet & 80 & 63 & 44,52 & 16,78 & \\
\hline Toplam & 127 & 100 & & & \\
\hline
\end{tabular}


Yapılan analiz sonucunda Tablo 4'te yer alan verilerde mobil internet kullanan katılımcıların 47 kişi olduğu ve tüm katılımcıların \%37'sini oluşturduğu, sabit internet kullanan katılımcıların 80 kişi olduğu ve tüm katılımcıların \%63'ünü oluşturduğu görülmektedir. Yapılan ANOVA analizi sonucunda $p$ değeri .465 bulunmuştur. Bulunan $\mathrm{p}$ değeri $\mathrm{p}>.05$ alpha değerinden büyük olduğu için üniversite öğrencilerinin koronavirüs küresel salgını sürecinde dijital oyun bağımlılıkları düzeylerinde istatistiksel olarak anlamlı bir fark bulunmadığını göstermektedir. İstatistiksel olarak anlamlı bir fark bulunmamasına rağmen dijital oyun bağımlılığı ölçeğinden alınan puanlara bakıldığında hem mobil internet bağlantısı hem de sabit internet bağlantısı kullanan katılımcıların dijital oyun bağımlılığı düzeylerinde riskli grupta bulunduklarını göstermektedir.

\section{Üẹüncü Alt Probleme İlişkin Bulgular}

Araştırmanın "Üniversite öğrencilerinin bulundukları yaş aralıkları değişkenine göre dijital oyun bağımlılık düzeylerinde anlamlı bir fark var mıdır?" alt problemine ilişkin bulgularına Tablo 5'te yer verilmiştir.

Tablo 5: Yaş Aralıkları Değişkenine İlişkin Veriler

\begin{tabular}{lcccc}
\hline Yaş Aralıkları & $\mathbf{N}$ & $\overline{\mathbf{X}}$ & $\mathbf{S D}$ & $\mathbf{p}$ \\
\hline 20 Yaş ve Altı & 43 & 44,81 & 15,33 & \\
$21-24$ Yaş Arası & 60 & 42,86 & 19,97 & .073 \\
25 Yaş ve Üstü & 24 & 53,08 & 19,46 & \\
\hline Toplam & 127 & 45,45 & 18,67 & \\
\hline
\end{tabular}

Yapılan analiz sonucunda Tablo 5'teki verilere bakıldığında 20 yaş ve altında bulunan 43 katılımcının olduğu, 21-24 yaş aralığında bulunan 60 katılımcının olduğu, 25 yaş ve üstü 24 katılımcının oluğu görülmektedir. Yapılan analiz sonucunda p değeri .073 bulunmuştur. Bulunan bu değer p $>.05$ alpha değerinden büyük olduğu için üniversite öğrencilerinin koronavirüs küresel salgını sürecinde dijital oyun bağımlılıkları düzeylerinde öğrencilerin bulundukları yaş aralıklarına göre istatistiksel olarak anlamlı bir fark bulunmadığını göstermektedir. Dijital oyun bağımlılığı ölçeğinden alınan ortalama puanlara bakıldığında tüm yaş gruplarının riskli grupta yer aldığı görülmektedir.

\section{Dördüncü Alt Probleme İlişkin Bulgular}

Araştırmanın "Üniversite öğrencilerinin kullandıkları teknolojik cihaz değişkenine göre dijital oyun bağımlılık düzeylerinde anlamlı bir fark var mıdır?” alt problemine ilişkin bulgularına Tablo 6'da yer verilmiştir.

Tablo 6: Kullanılan Teknolojik Cihaz Değişkenine İlişkin Veriler

\begin{tabular}{lcccc}
\hline Cihaz Türü & $\mathbf{N}$ & $\overline{\mathbf{X}}$ & SD & $\mathbf{p}$ \\
\hline Telefon & 102 & 43,39 & 18,01 & \\
Bilgisayar & 18 & 52,88 & 16,50 & .037 \\
Tablet & 7 & 56,42 & 26,63 & \\
\hline Toplam & 127 & 45,45 & 18,67 & \\
\hline
\end{tabular}

Yapılan ANOVA analizi sonucunda Tablo 6'daki verilere bakıldığında telefon kullanan 102 katılımcı, bilgisayar kullanan 18 katılımcı ve tablet kullanan 7 katılımcı olduğu görülmektedir. Analiz sonucunda $\mathrm{p}$ değeri .037 bulunmuştur. Bulunan $\mathrm{p}$ değeri $\mathrm{p}<.05$ alpha değerinden küçük olduğundan dolayı koronavirüs küresel salgını sürecinde üniversite öğrencilerinin dijital oyun bağımlılıkları düzeyinde kullanılan cihaz türüne göre istatistiksel olarak anlamlı bir fark bulunmaktadır. Katılımcıların dijital oyun bağımlılığı ölçeğinden aldıkları puanlara bakıldığında en yüksek puanı tablet kullanan katılımcıların aldığı ve bunu bilgisayar kullanan kullanıcıların takip ettiği görülmekte, ölçekten alınan en düşük puanı ise telefon kullanan katılımcıların olduğu görülmektedir. Bu da tablet ve bilgisayar kullanan katılımcıların daha yüksek dijital oyun bağımlılık düzeyine sahip olduğunu göstermektedir.

Beşinci Alt Probleme İlişkin Bulgular

Araştırmanın "Üniversite öğrencilerinin bulundukları sınıf düzeyi değişkenine göre dijital oyun bağımlılık düzeylerinde anlamlı bir fark var mıdır?” alt problemine ilişkin bulgularına Tablo 7'de yer verilmiştir. 
Tablo 7: Sınıf Düzeyi Değişkenine İlişkin Veriler

\begin{tabular}{lcccc}
\hline Sinıf Düzeyi & N & $\overline{\mathbf{X}}$ & SD & p \\
\hline 1. Sinıf & 46 & 44,67 & 17,79 & \\
2. Sinıf & 26 & 49,73 & 19,81 & .571 \\
3. Sinıf & 27 & 42,70 & 21,58 & \\
4. Sinıf & 28 & 45,42 & 16,16 & \\
\hline Toplam & 127 & 45,45 & 18,67 & \\
\hline
\end{tabular}

Yapılan analiz sonucunda Tablo 7'deki veriler incelendiğinde katılımcıların 46's1 1. sınıf, 26's1 2. sınıf, 27'si 3. sınıf ve 28'inin 4. sınıf olduğu görülmektedir. Analiz sonucunda p değeri .571 bulunmuştur. Bulunan bu değer $p>.05$ alpha değerinden büyük olduğu için üniversite öğrencilerinin koronavirüs küresel salgını sürecinde dijital oyun bağımlılıkları düzeylerinde öğrencilerin bulundukları sınıf düzeyi değişkenine göre istatistiksel olarak anlamlı bir fark bulunmadığını göstermektedir. Dijital oyun bağımlılığı ölçeğinden alınan puanlara bakıldığında tüm sınıf düzeylerinin birbirlerine yakın puanlar aldığı görülmektedir.

\section{Altıncı Alt Probleme İlişkin Bulgular}

Araştırmanın "Üniversite öğrencilerinin fiziksel etkinliklere katılma durumu değişkenine göre dijital oyun bağımlılık düzeylerinde anlamlı bir fark var mıdır?” alt problemine ilişkin bulgularına Tablo 8'de yer verilmiștir.

Tablo 8: Fiziksel Etkinliklere Katılma Durumu Değişkenine İlişkin Veriler

\begin{tabular}{lcccc}
\hline $\begin{array}{l}\text { Fiziksel Etkinliklere Katılma } \\
\text { Durumu }\end{array}$ & $\mathbf{N}$ & $\overline{\mathbf{X}}$ & SD & $\mathbf{p}$ \\
\hline Hiç Katılmıyorum & 34 & 47,58 & 21,37 & \\
Az Katıliyorum & 42 & 48,45 & 18,00 & .174 \\
Arada Sırada & 30 & 44,00 & 20,32 & \\
Her Fırsatta & 21 & 38,09 & 9,63 & \\
\hline Toplam & 127 & 45,45 & 18,67 & \\
\hline
\end{tabular}

Yapılan analiz sonucunda Tablo 8'deki verilere bakıldığında katılımcıların 34'ü fiziksel etkinliklere hiç katılmadığını, 42'sinin az katıldığını, 30'unun arada sırada katıldığını ve 21 'inin fiziksel etkinliklere her firsatta katıldığını bildirmişlerdir. Analiz sonucunda p değeri 174 bulunmuştur. Bulunan bu değer $\mathrm{p}>.05$ alpha değerinden büyük olduğu için üniversite öğrencilerinin koronavirüs küresel salgını sürecinde dijital oyun bağımlılıkları düzeylerinde öğrencilerin fiziksel etkinliklere katılma durumu değişkenine göre istatistiksel olarak anlamlı bir fark bulunmadığını göstermektedir. Dijital oyun bağımlılığg ölçeğinden alınan puanlara bakıldığında katılımcıların fiziksel etkinliklere katılma düzeyleri arttıkça dijital oyun bağımlılığı düzeylerinin düştüğünü göstermektedir.

\section{Yedinci Alt Probleme İlişkin Bulgular}

Araştırmanın "Üniversite öğrencilerinin bağımlılık yapıcı madde kullanım durumu değişkenine göre dijital oyun bağımlılık düzeylerinde anlamlı bir fark var mıdır?” alt problemine ilişkin bulgularına Tablo 9'da yer verilmiştir.

Tablo 9: Bağımlılık Yapıcı Madde Kullanma Durumu Değişkenine İlişkin Veriler

\begin{tabular}{lccccc}
\hline Madde Kullanımı & $\mathbf{N}$ & $\mathbf{\%}$ & $\overline{\mathbf{X}}$ & $\mathbf{S D}$ & $\mathbf{p}$ \\
\hline Evet & 23 & 18,1 & 57,39 & 22,39 & .001 \\
Hayır & 104 & 81,9 & 42,81 & 16,75 & \\
\hline Toplam & 127 & 100 & & & \\
\hline
\end{tabular}

Yapılan analiz sonucunda Tablo 9'daki veriler incelendiğinde bağımlılık yapıcı madde kullanan 23 katılımcının olduğu, bağımlılık yapıcı madde kullanmayan 104 katılımcı olduğu görülmektedir. Bağımlılık yapıcı madde kullanan kişiler tüm katılımcıların \%18,1'ini, madde kullanmayan kişilerin ise tüm katılımcıların \%81,9'unu oluşturduğu görülmektedir. Yapılan analiz sonucunda p değeri .001 
bulunmuştur. Bulunan bu değer $p<.05$ alpha değerinden küçük olduğu için üniversite öğrencilerinin koronavirüs küresel salgını sürecinde dijital oyun bağımlılıkları düzeylerinde öğrencilerin bağımlılık yapıcı madde kullanım durumuna göre istatistiksel olarak anlamlı bir fark bulunduğunu göstermektedir. Dijital oyun bağımlılı̆ğ ölçeğinden alınan puanlara bakıldığında bağımlılık yapıcı madde kullanan bireylerin 57,39 ortalama puan aldığ 1 görülmekte ve 43-63 aralı̆̆ında bulundukları için dijital oyun bağımlılıkları durumunda riskli grupta olduklarını göstermektedir.

\section{Sekizinci Alt Probleme İlişkin Bulgular}

Araştırmanın "Üniversite öğrencilerinin akademik başarı düzeyleri durumu değişkenine göre dijital oyun bağımlılık düzeylerinde anlamlı bir fark var mıdır?" alt problemine ilişkin bulgularına Tablo 10 'da yer verilmiştir.

Tablo 10: Akademik Başarı Düzeyi Değişkenine İlişkin Veriler

\begin{tabular}{lcccc}
\hline Akademik Başarı Düzeyi & $\mathbf{N}$ & $\overline{\mathbf{X}}$ & SD & p \\
\hline Düşük & 7 & 70,28 & 16,12 & \\
Normal & 78 & 45,19 & 18,41 & .001 \\
Yüksek & 42 & 41,45 & 16,66 & \\
\hline Toplam & 127 & 45,45 & 18,67 & \\
\hline
\end{tabular}

Yapılan analiz sonucunda Tablo 10'daki veriler incelendiğinde akademik başarısı düşük 7 katılımcının, akademik başarısı normal 78 katılımcının, akademik başarısı yüksek 42 katılımoının olduğu görülmektedir. Analiz sonucunda $\mathrm{p}$ değeri .001 bulunmuştur. Bulunan bu değer $\mathrm{p}<.05$ alpha değerinden küçük olduğu için üniversite öğrencilerinin koronavirüs küresel salgını sürecinde dijital oyun bağımlılıkları düzeylerinde akademik başarı durumlarına göre istatistiksel olarak anlamlı bir fark bulunduğunu göstermektedir. Dijital oyun bağımlılı̆̆ ölçeğinden alınan ortalama puanlara bakıldığında en yüksek ortalama puan 70,28 ile akademik başarısı düşük bireylerde olduğu en düşük ortalama puan 41,45 ile akademik başarısı yüksek bireylerde olduğu görülmektedir. Bu da akademik başarı düzeyinin artması dijital oyun bağımlılı̆̆ düzeyini düşürmektedir. Akademik başarısı düşük bireylerin dijital oyun bağımlılı̆̆ı ölçeğinden aldığı ortalama puan 64-84 Aralığında bulunmaktadır. Bu da akademik başarısı düşük bireylerin dijital oyun bağımlılığında bağımlı grup içerisinde yer aldığını göstermektedir.

\section{SONUC VE TARTIŞMA}

$\mathrm{Bu}$ araştırmada koronavirüs küresel salgını sürecinin yarattığı kısıtlama süreçleri sebebiyle üniversite öğrencilerinin dijital oyun bağımlılık düzeylerine nasıl etkide bulunduğunun araştırllip değerlendirilmesi amaçlanmıştır. Küresel salgın süreci insanların kendilerini birçok yönden kısıtlamaya sokmasına sebebiyet vermiştir. Birçok devlet koronavirüs hastalığının küresel bir salgın olması sebebi ile insan yaşamına kısıtlamalar getirmişlerdir. İnsan yaşamına getirilen kısıtlamalar insanların stres altına girmesi ve bu stres, kaygı durumundan kurtulmak için birçok yola başvurmalarına neden olmuştur. Dijital oyunlar insanların stres ve kaygı düzeylerini azaltmak için başvurdukları yollardan bir olmuştur.

Araştırmanın birinci alt problemindeki veriler incelendiğinde koronavirüs küresel salgını sürecinin üniversite öğrencilerinin dijital oyun bağımlllıkları düzeylerinde üniversite öğrencilerinin oynadıkları oyun türü değişkenine göre dijital oyun bağımlılık düzeylerinde istatistiksel olarak anlamlı bir farklılığa ulaşılmıştır. Spor, macera, savaş ve strateji oyunlarının dijital oyun bağımlılıklarında riskli grupta yer alması devam gerektiren oyunların daha çok bağımlılı̆ga neden olduğu düşünülmektedir. Bulmaca ve zekâ oyunlarının devam gerektirmeyen oyunlar grubunda yer alması ve diğer dijital oyun türleri gibi riskli bir bağımlılık puanına sahip olmaması da bunu desteklemektedir. Lemmens ve Hendriks'in (2016) çalışmasında da bağımlı oyun kullanıcıların en fazla savaş, silahlı oyunlar olduğunu belirtmesi de çalışmamızın bulguları açısından tutarlılık göstermektedir. Küresel salgın sürecinin sosyal yaşamda birçok etkide bulunması araştırdığımız tüm dijital oyun türlerinin oynanmasında artışa sebebiyet verdiğini göstermekte ve dijital oyun bağımlılığı ölçeğinden alınan puanların yüksek olması bulmaca ve zekâ oyunları dışındaki oyun türlerinin riskli grupta yer alması da bu düşüncemizi desteklediği düşünülmektedir.

Araştırmanın ikinci alt problemindeki verilere bakıldığında koronavirüs küresel salgını sürecinin üniversite öğrencilerinin dijital oyun bağımlılıkları düzeylerinde üniversite öğrencilerinin kullandıkları internet türü değişkenine göre dijital oyun bağımlılık düzeylerinde istatistiksel olarak anlamlı bir farklılığa ulaşılmamıştır ( $>$ >05). Yaptığımız çalışmanın bu hipotezine ait bulgular Göldağ'ın (2018) lise 
öğrencileri üzerinde yaptığı çalışma sonucunda ulaştığı bulgularla tutarlılık göstermemektedir. Göldağ’’n yaptığı çalışmada sabit internet bağlantısına sahip kişilerde dijital oyun bağımlılı̆̆ının yüksek olduğunu tespit etmiştir. Yaptığımız çalışma sonucunda her iki internet türünü kullanan bireylerin riskli grupta olduğu görülmekte ve mobil internet bağlantısına sahip bireylerin daha yüksek bağımlılığa sahip olduğu görülmektedir. Ulaşılan bu sonuç küresel salgın sürecinin yarattığı sıkıntıların bu durumu etkilediği ve aynı zamanda mobil cihazın daha kolay ulaşılması daha çok bağımlılık oluşturduğu düşünülmektedir.

Araştırmanın üçüncü alt problemindeki veriler incelendiğinde üniversite öğrencilerinin bulunduğu yaş aralığı değişkeni açısından dijital oyun bağımlılık düzeyleri arasında istatistiksel olarak anlamlı bir farklılığa ulaşılamamıştır. Yapılan analizler sonucunda incelenen tüm yaş gruplarının riskli grupta yer aldığı görülmektedir. İncelenen tüm yaş gruplarının riskli grupta yer alması küresel salgın sürecinin yarattığı kısıtlamalardan kaynaklandığı düşünülmektedir.

Araştırmanın dördüncü alt problemindeki veriler incelendiğinde koronavirüs küresel salgını sürecinin üniversite öğrencilerinin dijital oyun bağımlılıkları düzeylerinde üniversite öğrencilerinin kullandıkları cihaz türü değişkenine göre dijital oyun bağımlılık düzeylerinde istatistiksel olarak anlamlı bir farklılığa ulaşılmıştır. Ulaşılan bu sonuç bağımlılık düzeylerinin en yüksek tablet ve bilgisayar kullanıcılarında olduğu görülmektedir. Bu hipoteze ilişkin ulaşılan sonuçlar Mustafaoğlu ve Yasacı'nın (2018) yaptığı çalışma bulguları ile tutarlılık göstermektedir. Mustafaoğlu ve Yasacı dijital oyun bağımlılı̆ı̆ın oluştuğu kişilerde en fazla tablet kullandıklarını tespit etmişlerdir. Küresel salgın sürecinin bu duruma etkisi, bu cihazların kullanım süresini arttırmış ve tablet, bilgisayar ve akıllı telefon gibi teknolojik cihazları kullanan bireylerin riskli grupta yer almasına neden olduğu düşünülmektedir.

Araştırmanın beşinci alt problemindeki verilere bakıldığında salgın sürecinde sınıf düzeyi değişkeninin dijital oyun bağımlılıkları düzeylerindeki etkisi üzerinde istatistiksel olarak anlamlı bir farklılık bulunmamıştır. Farklılık bulunmamasına rağmen 1, 2, 3 ve 4 . sınıf düzeyinde bulunan öğrencilerin ölçekten aldıkları puanların riskli grupta yer aldığı görülmektedir. Bu durum salgın süreci sonucundaki kısıtlamalardan kaynaklandığı düşünülmektedir.

Araştırmanın altıncı alt problemindeki veriler incelendiğinde koronavirüs küresel salgını sürecinin üniversite öğrencilerinin dijital oyun bağımlllıkları düzeylerinde üniversite öğrencilerinin fiziksel etkinliklere katılma durumu değişkenine göre dijital oyun bağımlılık düzeylerinde istatistiksel olarak anlamlı bir farklılık bulunmamıştır. İstatistiksel bir farlılık bulunmamasına rağmen Literatürdeki birçok çalışma fiziksel etkinliklere katılma durumunun artışıla birlikte dijital oyun bağımlılık düzeyinin düştüğü tespit edilmiş̧ir (Demir ve Cicioğlu, 2018; Biddiss ve Irwin, 2010). Yedinci hipotez sonuçları incelendiğinde fiziksel etkinlik yapma düzeyinin artmasıyla birlikte dijital oyun bağımlıllğı ölçeğinden alınan puanların düştüğü gözlenmiş̧ir. Küresel salgın sürecinde yaşanan karantina süreçleri sosyal yaşamın kısıtlanması durumları fiziksel etkinliklerin yapılmasını sınırlandırmış ve bundan dolayı istatistiksel olarak anlamlı farklılık bulunmamasına neden olabileceği düşünülmektedir.

Araştırmanın yedinci dokuzuncu alt problemindeki veriler incelendiğinde bağımlılık yapıcı madde kullanma durumunun dijital oyun bağımlılıkları düzeylerine etkisinde istatistiksel olarak anlamlı farklılık bulunmuştur. Bağımlılık yapıcı madde kullanan bireylerin dijital oyun bağımlılık düzeylerinin yüksek olduğu tespit edilmiştir. Koç (2020) yaptığı çalışmada üniversite öğrencilerinde sigara, alkol ve benzeri bağımlılık yapıcı madde kullanan bireylerin dijital oyun bağımlılık düzeylerinin kullanmayan bireylere göre yüksek olduğunu tespit etmiştir ve bu çalışma bulguları bulgularımızla tutarlılık göstermektedir. Bağımlılık yapıcı maddelerin stres ve kaygı durumlarından bir kurtulma ve rahatlama yolu olarak algılayan bireylerin dijital oyun gibi bağımlılık yapıcı bir faktöre bağımlılık sağlayabileceği düşünülmektedir. Koronavirüs küresel salgını sürecinde insanların yoğun stres, kaygı yaşaması ve insanların bu durumlardan kurtulmak istemesi bağımlılık yapıcı dijital oyunlara yönelmelerine sebebiyet vermiştir.

Araştırmanın sekizinci alt problemindeki veriler incelendiğinde küresel salgın sürecinde üniversite öğrencilerinin akademik başarı durumlarına göre dijital oyun bağımlılıkları düzeyinde istatistiksel olarak anlamlı bir farklılık bulunmuştur. Bulunan bu farklılık akademik başarı düzeylerinin düşmesi ile dijital oyun bağımlılıklarının yükseldiğini göstermektedir. Dijital oyun bağımlılığı ölçeğinden alınan ortalama puanlara bakıldığında akademik başarısı düşük bireylerin bağımlı grup içerisinde yer aldığı görülmektedir. Akademik başarısı normal ve yüksek olan bireylerin riskli grupta yer alması salgın süreci sonucu yaşanan kısıtlamaların ve insanların yaşadığı kaygı ve stresten dolayı dijital oyunlara yönelmiş olabileceği düşünülmektedir. 


\section{Öneriler}

Çalışmanın daha büyük kitlelere uygulanması araştırmanın geçerlik ve güvenirliğine katkı sağlayacaktır. Dijital oyun bağımlılı̆̆ı oluşan ve oluşma tehlikesi olan bireyler için psikolojik destek alma programlarının geliştirilmesi faydalı olabilir. Dijital oyun bağımlılıklarını önleyici alternatif etkinlikler planlanabilir. Küresel salgın sürecinde kullanımı artış gösteren dijital oyunların kullanımına sınırlamalar getirilecek projeler geliştirilmeli. Bu araştırmada nicel yöntem kullanılmıştır. Benzer bir araştırma nitel yöntemle yürütülebilir.

\section{Etik Kurul Onay Bilgileri}

$\mathrm{Bu}$ araştırmanın yürütülebilmesi için Mardin Artuklu Üniversitesinden etik kurul izni alınmış ve "Yükseköğretim Kurumları Bilimsel Araştırma ve Yayın Etiği Yönergesi”nde yer alan tüm kurallara uyulmuştur.

Kurul Adı: Mardin Artuklu Üniversitesi Bilimsel Araştırma ve Yayın Etiği Kurulu

Karar Tarihi: 31.03 .2021

Karar Sayıs1: 2021/3-15

Belge Sayı Numaras1: E-79906804-050.06.04-10243

\section{KAYNAKÇA}

Ankara Kalkınma Ajansı. (2016). Dijital Oyun Sektörü Raporu. Ankara: Ankara Kalkınma Ajansı.

Biddiss, E. ve Irwin, J. (2010). Active Video Games to Promote Physical Activity in Children and Youth. Arch Pediatr Adolesc Med, 164(7), 664-672.

Çakmak, M.; Özdaş, F. ve Akın, M. A. (2020). Learning How to Learn Scale: A Study of Validity and Reliability. Educational Policy Analysis and Strategic Research, 15(3), 438-455.

Demir, F. ve Özdaş, F. (2020). Covid-19 Sürecindeki Uzaktan Eğitime İlişkin Öğretmen Görüşlerinin İncelenmesi. Milli Eğitim Dergisi, 49(1), 273-292.

Evran Acar, F. (2010). Sınıf Öğretmenliği Programindan Mezun Olan Öğretmenlerin Türkçe Dersine İlişkin Yeterliklerinin Değerlendirilmesi. Türk Ĕgitim Bilimleri Dergisi, 8(1), 89-115.

Fernandes, N. (2020). Economic Effects of Coronavirus Outbreak (COVID-19) on the World Economy. IESE Business School Working, 1240, 1-32.

Gentile, D. (2009). Pathological Video-Game Use Among Youth Ages 8 to 18: A National Study. Psychological Science, 20(5), 594-602.

Ghebreyesus, T. A. (2020). WHO Director-General's Opening Remarks at the Media Briefing on COVID-19.

Göldağ, B. (2018). Lise Öğrencilerinin Dijital Oyun Bağımlılık Düzeylerinin Demografik Özelliklerine Göre İncelenmesi. Yüzüncü Yll Üniversitesi Eğitim Fakültesi Dergisi, 15(1), 1287-1315.

Hazar, E. ve Hazar, Z. (2019). Üniversite Öğrencileri İçin Dijital Oyun Bağımlılı̆̆ı Ölçeği (Uyarlama Çalışması). Spor Bilimleri Araşstırmaları Dergisi, 4(2), 308-322.

Ho, C. S.; Chee, C. Y. ve Ho, R. C. (2020). Mental Health Strategies to Combat the Psychological Impact of Covid-19 Beyond Paranoia and Panic. Annals of the Academy of Medicine, Singapore, 49(3), $155-160$.

Hoque, A.; Shikha, F. A.; Hasanat, M. W.; Arif, I. ve Hamid, A. B. A. (2020). The Effect of Coronavirus (COVID-19) in the Tourism Industry in China. Asian Journal of Multidisciplinary Studies, 3(1), 52-58.

Karasar, N. (2012). Bilimsel Araştırma Yöntemi: Kavramlar, İlkeler, Teknikler. Ankara: Nobel Yayın Dağıtım.

Király, O.; Potenza M. N. ve Stein, D. J. (2020). Preventing Problematic Internet Use During the COVID-19 Pandemic: Consensus Guidance. Comprehensive Psychiatry, 100, 2-4.

Koç, A. K. (2020). Lise ve Üniversite Öğrencilerinde Internet Oyun Bağımlılığı Sıklığı ve Etkili Faktörler, (Yayımlanmamış Uzmanlık Tezi), (Danışman: Prof. Dr. Seçil Özkan), Ankara: Gazi Üniversitesi Tıp Fakültesi.

Kodaman, U. ve Dinç, M. (2016). Teknolojiye Bağımlı Yaşama!. İstanbul: Kültür Sanat Basımevi.

Lemmens, J. S. ve Hendriks, S. J. (2016). Addictive Online Games: Examining the Relationship Between Game Genres and Internet Gaming Disorder. Cyberpsychology, Behavior and Social Networking, 19(4), 270-276. 
Lemmens, J. S.; Valkenburg, P. M. ve Peter, J. (2009). Development and Validation of a Game Addiction Scale for Adolescents. Media Psychology, 12(1), 77-95.

Mustafaoğlu, R. ve Yasacı, Z. (2018). Dijital Oyun Oynamanın Çocukların Ruhsal ve Fiziksel Sağlı̆̆ı Üzerine Olumsuz Etkileri. Bağımlılık Dergisi, 19(3), 51-58.

Tarhan, N. (2016). Beyin ve Bağımlılık. Psikohayat, 0(7), 16-20.

Tekkurşun Demir, G. ve Cicioğlu, H. İ. (2018). Fiziksel Aktiviteye Katılım Motivasyonu Ölçeği (FAKMÖ): Geçerlik ve Güvenirlik Çalışması. International Journal of Human Sciences, 15(4), 2479-2492.

TÜBA. (2020). Covid 19 Pandemi Değerlendirme Raporu, Ankara. https://www.tuba.gov.tr/files/images/2020/kovidraporu/Covid-19\%20Raporu-Final\%2B.pdf adresinden 21.03.2021 tarihinde erişildi.

TÜBA. (2020). http://www.tuba.gov.tr/files/images/2020/kovidraporu/Covid-19\%20Raporu-Final+.pdf adresinden 21.03.2021 tarihine erișildi.

Ülker, Ü.; Acar, S. ve Bülbül, H. İ. (2017). Lisansüstü Öğrencilerin Eğitsel Dijital Oyunların Eğitim Amaçlı Kullanılmasına Yönelik Görüşleri. 11. Uluslararası Bilgisayar ve Öğretim Teknolojileri Seтроzуити (ICITS 2017) Tam Metin Bildiriler Kitabı İçinde (s. 111-118). Malatya.

WHO. (2020). Looking After Our Mental Health. https://www.who.int/campaigns/connecting-the-worldto-combatcoronavirus/healthyathome/healthyathome---mental-health adresinden 21.03 .2021 tarihinde erişildi.

Zheng, Y.; Goh, E. ve Wen, J. (2020). The Effects of Misleading Media Reports About Covid-19 on Chinese Tourists' Mental Health: A Perspective Article. Anatolia, 31(2), 337-340.

Zhu, N.; Zhang, D. ve Wang, W. (2020). A Novel Coronavirus from Patients With Pneumonia in China, 2019. The New England Journal of Medicine, 382(8), 727-733. 
